Michael Imhof

Malpractice in Surgery 


\section{Patient Safety}

Edited by

Oswald Sonntag and Mario Plebani

Volume 6 


\section{Malpractice in Surgery}

Safety Culture and Quality Management in the Hospital

\section{DE GRUYTER}




\section{Author}

Dr. med. Michael Imhof

Consultant surgeon

Auf der Schanz 96

97076 Würzburg

Germany

Email: praxis@dr-imhof.de

ISBN 978-3-11-027132-4 • e-ISBN 978-3-11-027160-7

Library of Congress Cataloging-in-Publication Data

A CIP catalog record for this book has been applied for at the Library of Congress

Bibliographic information published by the Deutsche Nationalbibliothek

The Deutsche Nationalbibliothek lists this publication in the Deutsche Nationalbibliografie; detailed bibliographic data are available in the Internet at http://dnb.dnb.de.

(C) 2013 Walter de Gruyter $\mathrm{GmbH}$, Berlin/Boston. The publisher, together with the authors and editors, has taken great pains to ensure that all information presented in this work (programs, applications, amounts, dosages, etc.) reflects the standard of knowledge at the time of publication. Despite careful manuscript preparation and proof correction, errors can nevertheless occur. Authors, editors and publisher disclaim all responsibility and for any errors or omissions or liability for the results obtained from use of the information, or parts thereof, contained in this work.

The citation of registered names, trade names, trade marks, etc. in this work does not imply, even in the absence of a specific statement, that such names are exempt from laws and regulations protecting trade marks etc. and therefore free for general use.

Translation: Constantijn Blondel, Leipzig

Typesetting: Compuscript Ltd., Shannon, Ireland

Printing: Hubert \& Co. GmbH \& Co. KG, Göttingen

Cover image: Comstock/Getty Images

Printed in Germany

$\otimes$ Printed on acid-free paper

www.degruyter.com 